\title{
Heterofunctionalization of Arenes by Electrophotocatalysis
}

Organo- and

Biocatalysis

\section{Key words}

alkoxylation

amination

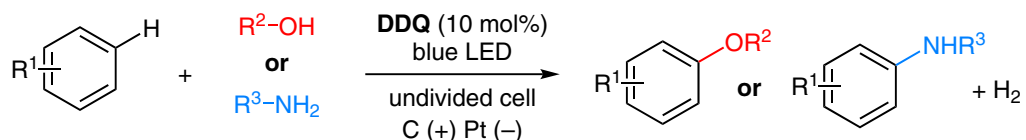

$\mathrm{R}^{1}=\mathrm{EWG}, \mathrm{Hal}, \mathrm{Alk}$

$R^{2}=H$, Alk, acyl

$\mathrm{C}(+) \mathrm{Pt}(-)$

$\mathrm{E}_{\text {cell }}=1.5 \mathrm{~V}$

$\mathrm{AcOH}, \mathrm{LiClO}_{4}$

$\mathrm{MeCN}$

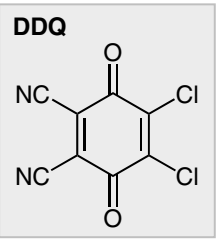

35 examples

$26-85 \%$ yield rr from $1: 1$ to $10: 1$

\section{electrophotocatalysis}

hydroxylation

photochemistry

Proposed mechanism:

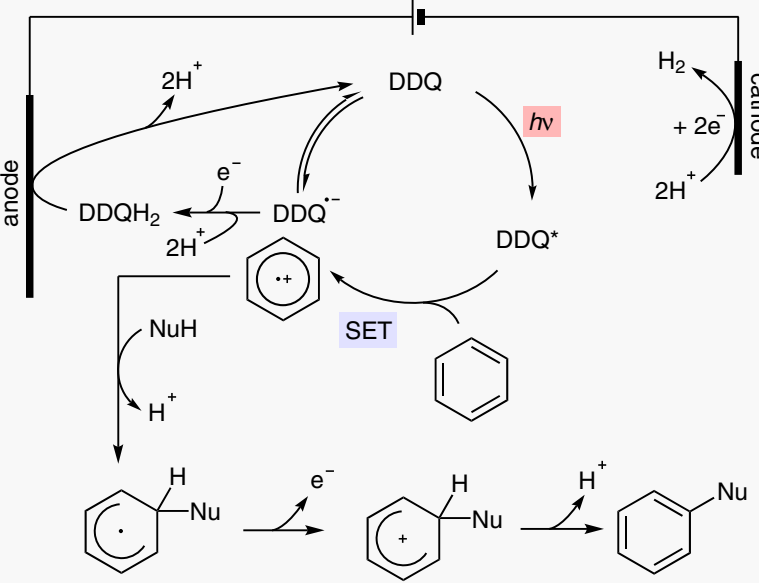

Arene heterofunctionalization examples:
$31 \%$ yield<smiles>C#CCCCOc1ccccc1</smiles><smiles>C[C@H](NC(=O)OCc1ccccc1)C(=O)Oc1ccccc1</smiles>

$30 \%$ yield
Arene hydroxylation examples:<smiles>Oc1ccccc1</smiles>
$80 \%$ yield<smiles>Oc1ccc(Cl)c(Cl)c1</smiles><smiles>O=C(OCCc1cc(Cl)[12c]cc1O)OCc1ccccc1</smiles>
$3: 1 \mathrm{C}_{\mathrm{A}}: \mathrm{C}_{\mathrm{B}}$<smiles>CC(=O)c1[12c][14c]([14CH3])[14cH][14cH][14c]1O</smiles>
$2: 1 \mathrm{C}_{\mathrm{A}}: \mathrm{C}_{\mathrm{B}}$<smiles>CC(C)(C)OCC(=O)NCC(=O)NCC(=O)OCc1cc(Cl)c[18c]c1O</smiles>$$
\mathrm{C}_{\mathrm{A}}: \mathrm{C}_{\mathrm{B}}
$$

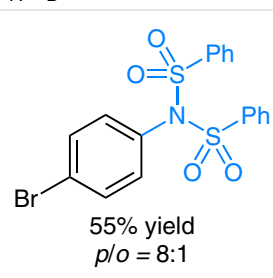

Significance: Huang and Lambert report an oxidant-free electrophotocatalytic heterofunctionalization of arenes, in which electron-deficient or electron-neutral arenes are readily functionalized with various oxygen and nitrogen nucleophiles. The reaction is shown to be compatible with a wide range of arenes, and moderate to good yields and regioselectivity are achieved.
Comment: The authors' reaction improves upon a previously reported arene heterofunctionalization using catalytic DDQ (see: P. Natarajan, B. König Eur. J. Org. Chem. 2021, 2145) by combining the photocatalytic and electrolytic processes to facilitate a lower catalyst loading, as well as eliminating the need for an additional oxidant, such as the potentially explosive mixture of tert-butyl nitrite and air. 